Psychological contract expectations of construction project managers

Running title: Psychological contract expectations

Andrew R.J. Dainty ${ }^{1 *}$, Ani B. Raiden ${ }^{1}$ and Richard H. Neale ${ }^{2}$

${ }^{1}$ Department of Civil and Building Engineering, Loughborough University, Leicestershire, LE11 3TU, UK. Tel. ++44 (0)1509 222884, Fax. ++44 ( 0)1509 222981.

${ }^{2}$ School of Technology, University of Glamorgan, Pontypridd, RCT, CF37 1DL, UK.

*Author for correspondence (Email a.r.j.dainty@lboro.ac.uk) 


\title{
Psychological contract expectations of construction project managers
}

\begin{abstract}
The past 20 years have seen a period of fundamental change for many construction businesses as they have restructured, downsized, de-layered, merged and de-merged in order to survive turbulent markets and rapidly changing demand cycles. Such change places significant new pressures, challenges and constraints on the employer/employee relationship. Whereas in the past employees could rely upon fairly stable job roles, structures and intra-firm relationships, the new human resource management (HRM) orthodoxy focuses on empowerment, teamwork, flexibility and management competence. In this paper, it is argued that these changes are likely to have reconstituted employee expectations of the less formal aspects of the employment relationship, known collectively as the psychological contract. This hypothesis was explored through inductive research which examined the antecedents, formation, breach and violation of the psychological contract of 30 construction project managers. The findings revealed the existence of a dynamic and reciprocal relationship between project managers and their employers. However, they also suggested that the ongoing expansion and restructuring of construction firms is gradually shifting the employment relationship towards transactional psychological contracts characterized by mutual self-interest and a lack of organizational commitment from employees. Guidance is provided as to how construction firms can begin to address this issue, through HRM practices which emphasize reciprocity, loyalty, trust and support between organizations and their key production managers.
\end{abstract}

Keywords: human resource management, psychological contracts, project managers, staff retention. 


\section{INTRODUCTION}

Many large construction organizations have undergone a period of significant change over the last 20 years. They have effectively become managers of the construction process, rather than direct labour employers (Druker et al, 1996). This change is reflected in the consolidation of the construction contracting market within the UK, where the numbers of large organizations (employing over 300 people) has grown exponentially during the period of steady growth between 1994 and 2001, increasing from 174 to 253 (DTI, 2002). This expansion of firms has occurred largely at the expense of the number of smallmedium sized firms, which has declined from 194,483 to 167,870 over the same period. At the same time, successive government and intuitional reports have demanded improvements in process integration, people management practices and outturn performance, which have gradually raised client expectations of the industry's capabilities (Latham, 1994; Egan, 1998; Strategic Forum, 2002). In order to respond to these pressures and other demands on their businesses, many organizations have "de-layered" their structures (by removing middle management positions and shortening reporting lines), redesigned their job roles and functions and reduced bureaucracy. Throughout this transition the project management function has grown in stature and importance within construction firms. This is particularly the case within large contracting organizations where companies have empowered their managers with greater responsibility for the efficacy of the production effort (Dainty et al, 2002).

Project managers now have greater responsibility for managing the multiplicity of new relationships which have occurred as a result of organizational and industry change. Indeed, strategic alliances, joint ventures, increased outsourcing, mergers and virtual organizations have all acted to reconstitute HRM patterns, roles and responsibilities within 
many modern organizations (Sparrow, 1998). Construction project managers therefore offer functional flexibility by accepting new and parallel responsibilities in addition to those that they have been used to. These changes have arguably led to project managers becoming the key human resource for the modern contracting organization.

Within the UK, reports abound of industry concerns over the turnover and wastage of competent project managers (Kahn, 1995; Ford, 1997; Cavill, 1999). Such concerns have been fuelled by years of falling enrolments to construction degree courses which have taken their toll on the supply of future managers (see Barrick, 2001; Byfield, 2001). Thus, reducing staff turnover and retaining key operational managers have become core strategic imperatives for most organizations (Rethinking Construction, 2000). Retaining key managerial staff relies upon an employment culture in which employees work for and develop the organization in a spirit of cooperation and involvement. However, the new levels of expectation on project managers may be placing considerable strain on the employment relationship. For example, recent evidence suggests that construction professionals are experiencing extreme occupational stress (Sutherland and Davidson, 1993). This is driving some managers out of the industry altogether (Sweet, 2002), and those who remain have found themselves having to cope with severe tensions in their work/life balance (Lingard and Sublet, 2002).

The inevitable result of the increased expectations put upon project managers is that they will expect more from their employers in return. This assertion is supported by reports of increasing salary levels and performance-based incentives now demanded by this key occupational group (Knutt, 1997). However, such expectations are likely to extend beyond remunerative reward, to encompass less formal requirements such as opportunities for career development, job security and better work/life balance. These are embodied within 
the psychological contract; the perceptions of both organization and individual as to the reciprocal promises and obligations implied within the employment relationship (see Guest and Conway, 2002). This paper explores the nature and content of the psychological contract from the perspective of UK contractors' project managers, in order that a fuller understanding of the causes of employee turnover can be ascertained. Such an insight should inform organizational HRM strategies which maintain the employment relationship and reduce staff turnover amongst this key occupational group.

\section{The Psychological Contract Construct}

This origins of psychological contract can be traced back to the early 1960s and the work or Argyris (1960) and Schien (1980). However, it is perhaps the work of Rousseau (1989; 1990; 2001) which has defined today's understanding of this important construct. One of the fundamental assumptions related to the existence of psychological contracts is that of reciprocity (Rousseau and Parks, 1993). This infers a mutual expectation of commitment from employer and employee, or a two-way exchange of perceived promises and obligations (Guest and Conway, 2000). In this context, Rousseau (1989) described the psychological contract as a "reciprocal exchange agreement" between the employee and the employer, a two-way exchange process rather than an employer-imposed and defined relationship (see Herriot and Pemberton, 1997). The implication is that in addition to the 'hard' areas of the employment contract that have to be met, a 'soft' set of expectations held by the employee also have to be organized and managed (Sparrow, 1998).

Within the relationship defined by the psychological contract, the employer and the employee inform, negotiate, monitor and then re-negotiate (or exit) the employment 
relationship. Thus, its nature and content depends upon the circumstances of the firm and the role of the individual within it. According to Rousseau (1995), the psychological contract can be positioned anywhere along a continuum bounded by two distinct theoretical types. These are: relational contracts - long-term, open ended relationships within unitary organizations which lead to the exchange of loyalty, trust and support; and transactional contracts - short-term relationships set within pluralistic organizational contexts and characterized by mutual self-interest. Regardless of where psychological contracts sit within the transactional-relational continuum, they should be seen as interactive and dynamic (Herriot and Pemberton, 1996). Employers should not assume that they will remain static in the context of the continually changing business environment in which organizations operate and the shifting structures and priorities which accommodate them.

Understanding and meeting psychological contract expectations is key to the success of any organization. This is because a failure to meet individual expectations can lead to their breach or violation, which in turn, can lead to a breakdown in the employment relationship. A breach of a psychological contract is defined as where the employee sees their organization as failing to meet one or more of their obligations. A violation infers that the employee feels frustration, anger or resentment that can lead to a fundamental deterioration in trust relations (Robinson, 1996; Morrison and Robinson, 1997). This leads to de-motivation, a reduction in job satisfaction and a decline in organizational commitment (Reichers et al, 1997; Robinson and Rousseau, 1994). Consequently, understanding the content of psychological contract is key to understanding the factors which lie behind employee turnover. 
It is important to note that the psychological contract construct is not without its critics. The term has been used to describe different phenomena, which has rendered it a poorly defined concept, and one which can effectively be "all things to all people" (Roehling, 1997). This ignores the reality that different people have different deals and expectations and that, even when they are similar, they may be perceived in a different way. Thus, understanding psychological contracts demands an empirical approach that is capable of unravelling individual perspectives, perceptions and expectations of the employment relationship within the organizational context in which they are embedded.

\section{The need for research into the psychological contract of construction project} managers

Despite the changes that have enveloped the industry and the resulting demands on project managers, little attention has been paid to the impact of such change on the employment relationship. Indeed, relatively little attention has been focused on their antecedents, formation and content per se (Rousseau, 2001; Guest and Conway, 2002). This paper seeks to begin to address this knowledge gap within the construction sector by exploring the psychological contracts of construction project managers. It aims to establish how aspects of organizational HRM policy have influenced the needs and expectations of those working within the sector, and to identify where psychological contract breach and/or violation have occurred. Such an insight should inform the development of more responsive HRM policies which ensure a commitment and loyalty towards construction organizations from this key management group. 
Given the dynamic and uncertain nature of the construction industry, it is reasonable to hypothesize that an incongruity may exist between organizational policy and the career needs of the individual. If this is the case, then this may explain why employees seek to develop their careers within competitor companies, or even outside of the industry altogether. Thus, this paper also questions whether the rhetorical promotion of project manager autonomy, involvement and empowerment actually engenders a reality of reciprocity and mutual respect within the employment relationship. 


\section{METHODOLOGY}

An inherent problem with exploring psychological contracts is that by their very nature they are hard to define until they have been breached or violated. Even breach and violation are difficult to identify as they can prompt widely contrasting behavioural responses (Rousseau, 1995). This renders the identification of psychological contract contents extremely problematic. Previous studies have tended to use attitudinal-rating scales to explore the nature and content of the psychological contract (for example Rousseau, 1990; Robinson et al, 1994; McDonald and Makin, 2000). These essentially involve the researcher choosing transactional and relational aspects and then measuring employee perceptions of their employers' obligations towards them. A problem with this approach is that it necessarily restricts exploration to 'implied contracts', where there exists a great deal of consensus about obligations which are routinely met. However, as Herriot et al (1997) point out, the psychological contract is specific to individuals, and so to understand fully it requires an understanding of both reciprocity and generosity as part of individual employment relationships. This demands a more expansive and interpretative approach to their investigation.

Given the paucity of previous research into the nature of psychological contract in construction, the researchers did not have an a priori knowledge of the content of the psychological contract from which an interview schedule could be derived. Accordingly, contractors' project managers were interviewed using a comprehensive semi-structured research instrument containing open-ended questions in order to elicit the full range of psychological contract contents salient to employment within the construction sector. The informants were asked to discuss every aspect of their employment relationship in-depth from their own frame of reference. Whilst this was time consuming and restrictive in terms 
of sample size, organizational HRM strategies could be explored in terms of their precise impact on the attitudes and perspectives of those taking part. For example, rather than asking a dichotomous question as to whether psychological contract violation had occurred, unfulfilled expectations could be explored in terms of their relative and cumulative effect on the employment relationship allowing those issues most fundamental to psychological contract breach to be discerned. A total of 30 managers were selected who managed projects across many sub-sectors of the industry. They all worked for three of the UK's largest contracting organizations and managed projects valued at $£ 10$ million or over. They had overall responsibility for the construction production function on site rather than overall responsibility for the project on behalf of the client.

The interview data were transcribed verbatim and then analysed using the qualitative data analysis package QSR NUD•IST NVIVO ${ }^{T M}$. This package facilitates the effective handling and manipulation of qualitative data using rich text and other formatting with the ability to edit, visually code and link documents as they are created, filtered, managed and searched. It promotes the hierarchical classification and subsequent modelling of concepts under both predefined headings (derived from the literature) and those induced from the data itself. This package is particularly effective for analysing large and loosely structured datasets and for testing theoretical propositions inductively as the analysis progresses. In order to structure the analysis, an initial psychological contract content classification was derived from a recent study conducted by McDonald and Makin (2000). This combined elements of Rousseau's (1990) factors and a more interpretative list developed by Herriot et al (1997) to produce a framework of three key factors reflecting the transactional nature of employer obligations, and nine which reflected the relational nature of employer obligations. This classification provided an initial framework from which psychological contract contents could be explored. 


\section{RESULTS}

The results of the study are presented below in accordance with the organizational obligation categories refined by McDonald and Makin (2000). They have been subcategorised in terms of whether they represented transactional or relational aspects of the employment relationship. It should be emphasized that these issues constitute only those unambiguously discussed by the majority of the informant group in the interests of brevity.

\section{Transactional employer obligations}

\section{Salary}

There was a consensus amongst most informants that there was little differential in salary levels between organizations. Nevertheless, this did not detract from their significance as a de-motivating (or hygiene) factor. Notably, remuneration amongst craft workers and first line supervisor staff had risen significantly above that of many project managers, so long as they worked extended hours. This had led to a belief that the role of the project manager had been devalued, despite their crucial importance to the efficacy of the production function. Many complained that they were only remunerated for their contracted working hours, despite committing many more in order to secure successful project outcomes. 
Ensuring fair and equitable remunerative packages within organizations formed another key expectation of the employment relationship. All three organizations tended to operate fairly autonomous functional and/or regional operating divisions, in which a number of senior managers were empowered to decide upon their subordinate's salary scales. However, interaction between project managers from different operating companies through training courses and occasional staff transfers had led to inconsistencies divisions being highlighted. Furthermore, a series of mergers and acquisitions had also led to misalignment between the salary scales of the original organizations. These factors had combined to create severe tensions between managers at the same functional level and resentment towards employers for their inequitable treatment of their occupational group.

Another important finding relating to remuneration concerned the acceptance of lower salary levels in what was termed as a "trade-off" by some project managers. In these cases, employees were willing to accept lower packages as part of their transactional relationship with their employer in return for relational aspects of their psychological contract expectations being met. For example, for many working within a regional business, the advantage of being able to work close to home offset the remunerative advantages of working away for long periods. Thus, organizations could easily reduce their transactional salary costs by taking account of employees' other needs through effective deployment practices.

\section{Benefits}

A significant transactional expectation of the employment relationship concerned additional employment benefits which did not form part of the basic salary payment. Given the 
consistency of salary levels within the industry, these elements provided the differential between the packages offered by different employers. Key amongst such benefits were company vehicles, an expected reward for working in a transient project-based sector. However, company vehicles had added relevance in the context of project managers' employment relationships, as they were deemed to be an important indicator of organizational status and thus, a key negotiable element of the reward package. Employers had used such benefits as a lever to attract new managers to their organization or to retain managers who felt that they were experiencing a lack of progression opportunity. Other benefits included membership of healthcare, pension and share option schemes. As was the case for remuneration, avoiding psychological contract breach relied upon transparency and consistency in terms of allocating benefits across the organization. Managers quickly became disillusioned when they found that colleagues had secured improved benefit packages.

\section{Performance linked to pay}

Many of those interviewed received a performance-related bonus in terms of an annual award linked to company profits, rather than individual or project performance. The fairness of this approach was appreciated insofar as it circumvented the inherent problems of measuring performance against project outcomes, which can be affected by factors outside of a project manager's direct control. However, by the same token, these schemes had led many to perceive that their employers did not recognize their individual efforts and contributions. Some employers had instituted a voluntary share ownership scheme where employees were rewarded in share options according to their length of service. Whilst take-up of such schemes had been high, and the tenure-linked incentive of 
share options effective in terms of encouraging loyalty amongst project managers, this also did little to reward individual management competency and performance.

\section{Relational employer obligations}

4. Recognition of contribution to the organization

Recognition was a significant issue for the managers interviewed as part of this study. Significantly, whilst achieving outturn performance targets led to recognition of their efforts from senior managers, their formative efforts in achieving these outcomes often went unnoticed. For example, working additional hours or making special efforts to mitigate problems and maintain good client relations were seen as necessary and expected. However, in some cases, the perfunctory attitudes of senior managers had contributed to a view that organizational concerns cantered on commercial issues to the detriment of the other indicators of project success. This was particularly salient given employer expectations that project managers would motivate and enthuse their own teams during a project's lifetime. This demanded that project managers themselves recognized the individual contribution of each of their team members and so had raised awareness of recognition as an important aspect of maintaining a positive employment relationship.

\section{Training}

Project managers' needs with regards to training did not form a significant constituent of the psychological contract. All firms were required to provide a basic level of training 
provision and all had committed significantly more resources to human resource development activities. The only significant factor related to training which had led to psychological contract breach was where employees had not been granted the time to undertake training and professional development activities. Pressures placed upon project-based staff often meant that spending time away from managing the production function could be detrimental to project success. Again, it was the perception of inequitable treatment rather than a lack of training per se which had led to psychological contract breach.

\section{Job security}

At the time that the interviews were carried out (2001-2002), job security was not a major concern for the project managers interviewed as both client demand and industry output was relatively buoyant. However, there remained an expectation, particularly from longerstanding employees, that employers should make particular efforts to avoid redundancies in the longer-term. Thus, job security was highly valued by project managers in exchange for their loyalty, flexibility and willingness to engage in additional non-project related activities such as the career management of their own subordinates.

\section{Career development}

A psychological contract implication of the industry's apparent propensity to move towards flatter management structures was the resultant reduction in vertical promotion opportunities. This had not been paralleled by a concurrent shift in career development 
expectations towards lateral and functionally oriented career paths. Rather, the majority of project managers retained aspirations of promotion, particularly in terms of progressing to office-based senior management levels. Little or no formal succession planning seemed to be in place to manage the career development/promotion process effectively. This had led some project managers to regard the devolution of responsibility to the project level as symptomatic of an attempt to reduce opportunities for career advancement. Managers who did not strive to achieve senior management status found a lack of opportunity for career advancement within their occupational role. Notwithstanding this concern, there was also a widely held perception that functioning as an effective project manager would increase the likelihood that employers would wish to retain them in this position. Whilst some perceived this to be because they were the key managers overseeing the core profit centres of the organization, they also believed that the transactional elements of their relationship should reflect this important responsibility.

\section{Recognition and feedback on performance}

Project managers discussed recognition and feedback on two levels. Firstly, they discussed formal recognition through the performance management system. This aspect of the HRM function was generally regarded as underdeveloped within the firms taking part in this study. There was a general belief that career development was a largely selfmanaged process for project managers and that little organizational support was available. The second way in which recognition was discussed was in relation to informal feedback on performance. Here, most project managers had effective, fairly informal working relationships with their line managers. The only caveat to this was where an expansion in activities had led to an increase in senior managers responsibility and hence, a 
subsequent lack of time to feed back on the individual achievements of their project-based managers. In these cases senior managers had relied upon the formal assessments carried out through the performance management system, which were ineffective as was discussed above.

9. Fairness and justice on personnel procedures

Very few project managers were aware of the existence of organizational policies and procedures which engendered fair and equitable treatment with regards to HRM decisions. Rather, most felt that a culture had developed in which grievances were dealt with informally, without the need for recourse to formal mechanisms and policies. The individualistic and approachable demeanour of senior managers has supported this informality, where each had effectively evolved their own ways of managing HRM issues. However, this had led to there being little coherence and problems in terms of misalignment between different divisions. Furthermore, as is discussed above, the expansion of companies had diminished the personal contact with line managers, thereby reinforcing the need for formal organizational policy and improved communication to ensure fair and accountable HRM-related decisions.

\section{Consultation and communication with employees}

Communication was a particular problem for staff based on dispersed projects, particularly for those who had little contact with the head office senior management. Whereas in the past, construction firms had tended to be small enough to rely upon informal channels of 
communication, expansions and mergers had led the construction organizations to face serious problems in terms of managing the HRM consultation process. There had been a noticeable deterioration in the methods used to communicate with project staff despite the de-layering of organizational hierarchies, and increasingly project team members looked to project managers themselves to act as a conduit for important organizational information. Examples included information on up and coming projects, the performance of the operating division and overall organization and new policies on HRM-related issues such as pay and performance review. Similarly, demands were also placed on the project manager to channel concerns to senior management and to involve their subordinates in the consultation process. This multi-faceted role was not explicitly recognized by organizations, despite its relevance to the well-being and satisfaction of employees at all levels.

\section{Support with personal and family problems}

Given the age range of the informant group (32 - 56), work/life balance issues formed some of the most significant psychological expectation elements emerging from the analysis. This was an area of obligation where the organizations had been responsive in trying to accommodate their employees' needs. Many examples were given of where employers had managed to minimize the time their staff had to work away from home or travel long distances. Most project managers believed that their employers' efforts in this regard were in part reward for their flexibility in their early career and partially a reflection that some did not mind working in dispersed locations given the generous remunerative benefits available. Interestingly, some managers attempted to separate their personal and professional lives to such an extent that they did not consider the work/life balance issue to 
be particularly relevant to a discussion on employer obligations of the employment relationship. For this group (almost a third of those interviewed) coping with work/life balance issues were merely inherent aspects of working within a project-based industry.

\section{Promotion}

As was alluded to in point seven above, opportunities for promotion beyond the project level were scarce given the tendency to de-layer organizational hierarchies. Furthermore, promotion was seen as being employee-driven, rather than as part of organizational succession planning. However, notwithstanding this general trend, there were instances of where recent incumbents to project management positions had done so against their own wishes to enable their organization to cope with rapid expansion. These managers had been selected for promotion based on their performance in their previous functional role. However, the differences in managing the project as opposed to a specific production or financial function presented a significant challenge for some individuals. Notably, a different set of competencies and behaviours were required to manage the demands of upstream communication with clients and other project stakeholders. Thus, appropriate guidance and support with regards to promotion was fundamental to maintaining a positive psychological contract.

\section{DISCUSSION AND RECOMMENDATIONS}

The objective of this study was to examine the psychological contracts of construction project managers and to identify how and why the employment relationship can break down for this key occupational group. Care was taken throughout this analysis to avoid an 
oversimplification of the psychological contract by delineating employee views into positive and negative views of employment practices. Rather, the results reflected a variety of responses and perceptions from project managers, reflecting the individualistic nature of employee expectations of the employment relationship.

Notwithstanding the inherent variability in employee perspectives, this research has suggested that many project managers' psychological contracts are positioned towards the relational end of the relational-transactional continuum. It would seem that, whilst problems exist in terms of identifying career and development options for project managers, the empowerment engendered through de-layered structures and the emphasis on project-level autonomy has created an 'involvement climate' which has helped to sustain positive relations between employers and their key management group. Nevertheless, factors remain which threaten to undermine these relational contracts and hence, the retention of project managers in the long-term. These stem from the expansion and restructuring of construction organizations in an attempt to improve performance in response to increasing client expectations. These have impacted in the following ways:

a Firstly, organizations have sought to devolve many aspects of the management function to a project level, endowing their project managers with additional and parallel responsibilities in return for autonomy and control of their own workplace environment. This has demanded increased functional flexibility from project managers and has increased the demands put upon them as leaders of the production function. Whilst this has helped to engender trust and reciprocity within the employment relationship, it has also raised expectations in terms of the recognition and reward, which cannot always be met. 
- Secondly, organizations have tended to de-layer their structures, thereby removing many of the vertical promotional opportunities once available to project-based employees. Project managers, whilst benefiting from the increased responsibilities and empowerment afforded to them, are now restricted in terms of their opportunity for vertical development. Thus, de-layering of organizational hierarchies has simultaneously supported and corroded two key relational aspects of the employment relationship. However, it remains significant that construction organizations appear to have done little to dampen their employees' focus on vertical advancement.

- A third cause of disharmony concerns the relational aspects of the psychological contract. This emerged from the strains that rapid growth had brought to communication and personal interaction with senior managers. Whereas in the past project managers could rely on direct interaction with their line managers as a route to solving HRM related issues, enlargement had removed the informality of this relationship and had created a reliance upon formal mechanisms to resolve grievances. However, a lack of robust HRM mechanisms and protocols to support the reconstituted psychological contract emerging from this expansion threatens the generally positive relational contracts found within the organizations studied.

a Finally, in addition to the problems inherent within the depersonalisation of the employment relationship, discord was also apparent in the transactional aspects of the psychological contract. The current buoyancy of the construction industry in the UK, coupled to the tight labour market, had led to a higher profile for transactional aspects of the employment relationship in recent years. Indeed, given the positive nature of many relational aspects of the employment relationship, it is reasonable to 
surmise that breach or violation is more likely to occur where transactional elements dominate psychological contract content. For some project managers, it is clear that the benefits of reciprocity do not detract from their transactional expectations of increased reward in return for increased responsibility, commitment and accountability for outturn performance standards. Thus, the influence of remuneration as a hygiene factor remains, which presents a significant problem for construction firms whose salary levels are constrained by tight margins.

The culmination of these factors could threaten the current relational nature of the psychological contract. Fairness, transparency and equitability of HRM processes, along with recognition of individual employee performance, can only occur if underpinned by robust HRM mechanisms. However, the rapid expansion of many UK construction firms has not been paralleled by a concurrent development of approaches towards the management of expectation and reward necessary to retain managers working within the new HRM orthodoxy. In the longer-term, it is also apparent that the industry's approach towards its management of the production function has the potential to militate against the attractiveness of the industry to new entrants. A key aspect of the project management role is to take on considerable responsibility for all aspects the management function, which is bound to induce feelings of overburden and stress amongst all but the highest achieving managers. This does not render the industry an attractive career choice for the potential managers of the future. 


\section{Managing the New Psychological Contract}

What emerges from the preceding discussion is the need for construction organizations to manage the change resulting from expansion and enlargement, which has undoubtedly impacted on the psychosocial boundaries of project managers who have found themselves at the centre of this change process. Whilst organizations appear to have made efforts to empower and secure the involvement of these key managers, this has simultaneously raised their profile and marketability as valuable resources for other organizations. When considered in the context of the tight labour market, greater transactional expectations on behalf of project managers is inevitable. Avoiding inflationary pressures demands that construction firms attempt to maintain employee relations at the relational end of the psychological contract continuum. This demands that project managers are supported in achieving reconstituted career goals created by construction organizations in response to their employees' needs. This emphasizes the link between the career and the psychological contract. Indeed, Herriot (1992) defines an organizational career as a series of psychological contract renegotiations. It would seem that one such renegotiation must occur for incumbents to project manager positions, who have hitherto tended to follow a vertical promotion-oriented career path.

Hiltrop (1996) reviewed many research studies which have looked at the employment relationship in order to define a range of strategies which together could provide a relevant framework to help organizations to manage the changing psychological contract. Several of her suggested tools and techniques have been summarized in Table 1 below, along with the potential influence that they could have in construction organizations given the findings outlined within this paper. These offer a range of actions that could help to embed 
the new psychological contract in a way which accords with the reconstituted career opportunities of the project management era.

\section{Insert Table 1 Here}

Although this framework is useful for creating the kind of employment climate in which the relational content of the psychological contract predominates, it should not be seen as a panacea to the retention of construction project managers for several reasons. Firstly, as has been emphasized earlier in this paper, pluralistic solutions to the management of the psychological contract are likely to lead to as many negative outcomes as they are positive. The findings of this research have shown that construction companies would be well advised to adopt individualistic approaches towards the management of the HRM function generally, despite the additional time and cost that this entails. Secondly, it is thought to take around seven years to embed a new psychological contract (see Atkinson, 2002). As such, by the time that employment relationship changes fundamentally, the employment climate itself is likely to have changed. It is also important that employers remain cognizant of the fact that psychological contracts will not remain static in the context of a dynamic industry and competitive labour market. As such, they should continually review whether they are meeting their employees' changing expectations. This demands the continual review of organizational policy in terms of whether it supports relational (and transactional) psychological contracts. This can be achieved through effective performance management systems, regular employee surveys and exit interviews. Finally, the findings outlined within this paper were derived from a relatively small sample of managers working within the UK construction industry. Whilst aspects of the psychological contract content may be transferable to other organizations and countries, they must be explored within these specific cultural, structural and 
organizational contexts before they can be said to reflect the industry's employment relations.

\section{CONCLUSIONS}

The implication of the acknowledgement of the psychological contract is that in addition to the 'hard' areas of the employment relationship that have to be met, a 'soft' set of employee expectations also have to be organized, managed and fulfilled. The content of the psychological contract is an important constituent of employment relations and essential in gaining an understanding of the causes behind staff turnover. However, psychological contracts remain remarkably under-researched in construction. This research therefore set out to explore the nature of the relationship between construction organizations and their key management group, project managers, who are at the centre of the industry's drive to improve its operational performance.

It was hypothesized at the outset of this research that a tension would exist in the employment relationship given the increasing demands put upon project managers within modern construction organizations. This was posited as an explanation as to why employees seek to develop their careers within competitor companies, or even outside of the sector altogether. However, pluralistic transactional type contracts do not seem to prevail amongst the project managers interviewed as part of this study. Indeed, a fairly dynamic and reciprocal relationship emerged as characterizing the relational aspects of the psychological contract. Clear demonstrations of mutual reciprocity were apparent, suggesting the existence of a relational type psychological contract necessary for construction organization's to cope with the dynamic business environment in which they 
operate. Although there must be some caution with regards to generalisability of the results given the relatively small sample, the findings could have major implications in terms of understanding employment relations and transactions within the industry.

Despite the dominance of relational psychological contracts, the rapid expansion of construction firms is beginning to threaten this situation and hence, the retention of project managers. Whereas in the past, good relations had been underpinned by an individualistic approach to HRM, organizational expansion coupled with the flattening of organizational structures has placed new strains on the employment relationship. The reality is of course far more complex than the dichotomous picture created by the relational/transactional continuum; project managers expect all aspects of their employers' obligations to be met simultaneously, and failure to address any aspect can result in breach or violation. Nevertheless, it is incumbent on construction employers to propagate and maintain an employment climate in which reciprocity prevails over and above mutual self-interest from either party. To achieve this construction firms must develop HRM policy which emphasizes career development at the project level and which recognizes the contribution of the individual, rather than rely on pluralistic solutions to the management of the employment relationship. 


\section{References}

Argyris, C (1960) Understanding Organizational Behavior. The Dorsey Press, Inc. Homewood, III.

Atkinson, C (2002) Career management and the changing psychological contract. Career Development International, Vol.7, No.1, 14-23.

Barrick, A (2001) Summit to tackle university crisis, Building, 13 July.

Byfield, M.P. (2001) Graduate shortage: the key to civil engineering's future? ICE Proceedings: Civil Engineering, 144(4), 161-165.

Cavill, N. (1999) Where have all the QSs gone? Building, 26 March, 24-25.

Dainty, ARJ, Bryman, A and Price, ADF (2002) Empowerment Within The UK Construction Sector. Leadership and Organizational Development Journal. Vol.23, No.6, 333-342.

Druker, J. White, G. Hegewisch, A. and Mayne, L (1996) Between hard and soft HRM: human resource management in the construction industry. Construction Management and Economics, 14, 405-416.

DTI (2002) Construction Statistics Annual: 2002 Edition, The Stationary Office, Norwich.

Egan (1998) Rethinking Construction: The Report of the Construction Task Force. Department of the Environment, Transport and the Regions, London. 
Ford, J (1997) Better jobs, bad bosses and biscuit tins: the hopes and bugbears of construction professionals. Building, May 23, 1997, pp30-33.

Guest, DE and Conway, N (2002) Communication the psychological; contract: an employer perspective. Human Resource Management Journal, Vol. 12, No. 2, 22-38.

Kahn, T. (1995) Managing People in Built Environment Organizations. In (Waterhouse M and Crook, G Eds.), Management and Business Skills in the Built Environment, E \& FN Spon, Oxford, 159-174.

Herriot, P (1992) The Career Management Challenge, Sage, London.

Herriot, P, Manning, WEG and Kidd, JM (1997) The content of the psychological contract. British Journal of Management, Vol.8, 151-62.

Hiltrop, J.M. (1996) Managing the changing psychological contract. Employee Relations, Vol.19, No.1, 36-49.

Knutt, E. (1997) Careers: Recruitment Drivers. Building Careers Supplement, March, 4-6.

Latham, M (1994) Constructing the Team, HMSO, London.

Lingard, H. and Sublet, A., (2002), The impact of job and organisational demands on marital or relationship satisfaction and conflict among Australian civil engineers, Construction Management and Economics, Vol. 20 (6), 507-521. 
Morrison, E.W. and Robinson, S.L. (1997) When employees feel betrayed: A model of how psychological contract violation develops. Academy Management Review, 22(1), 226-257.

Rethinking Construction (2000) A Commitment to People - Our Biggest Asset, Report of the Movement for Innovation's working group on Respect for People, Strategic Forum for Construction, HMSO, London.

Reichers, A.E., Wanous, J.P. and Austin, J.T.T. (1997) Understanding and Management Cynicism about Organizational Change. Academy of Management Executive, 11 (1), 4860.

Robinson, S.L. and Rousseau, D.M. (1994) Violating the psychological contract: not the exception but the norm. Journal of Organisational Behaviour. 15, 245-259.

Robinson, SL, Kratz, MS and Rousseau, D (1994) Changing Obligations and the psychological contract: a longitudinal study. Academy of Management Journal, Vol.37, $137-52$.

Robinson, S.L. (1996) Trust and Breach of the Psychological Contract. Administrative Science Quarterly, 41 (4), 574-600.

Roehling, MV (1997) The origins and early development of the psychological contract construct. Journal of Management History, Vol.3, No.2, 204-217. 
Rousseau, DM (1989) Psychological and implied contracts in organizations. Employee Responsibilities and Rights Journal, Vol.2, No.2, 121-139.

Rousseau, DM (1990) New hire perceptions of their own and their employer's obligations: a study of psychological contracts. Journal of Organizational Behavior, Vol.11, 389-400. Rousseau, DM (1995) Psychological Contracts in Organizations: Understanding Written and Unwritten Agreements, Sage, London.

Rousseau, DM (2001) Schema, promise and mutuality: The building blocks of the psychological contract. Journal of Occupational and Organizational Psychology, Vol.74, 511-541.

Rousseau, DM and Parks, JM (1993) The Contracts of Individuals and Organisation. In LL Cummings and BM Straw (Eds.) Research in Organisational Behaviour, 15, JAI Press, Greenwich, CT.

McDonald, DJ and Makin, PJ (2000) The psychological contract, organisational commitment and job satisfaction of temporary staff. Leadership and Organization Development Journal, Vol.21, No.2, 84-91.

Schein, EH (1980) Organizational Psychology ( $3^{\text {rd }}$ Ed.), Prentice-Hall, Englewood Cliffs, NJ. 
Sparrow, P. (1998) New organisational forms, processes, jobs and psychological contracts: Resolving the HRM issues. In (Sparrow, P. and Marchington, M. Eds.) Human Resource Management: The New Agenda. Pitman, London, 117-141.

Strategic Forum (2002) Accelerating Change. Strategic Forum for Construction, Department of Trade and Industry, London.

Sutherland, V., \& Davidson, M.J. (1993). Using a stress audit: The construction site manager experience in the UK. Work \& Stress. Vol 7(3), 273-286.

Sweet, R (2002) Breaking Point, Construction Manager, June, 2002, 14-18. 
Table 1: Mechanisms for securing positive psychological contracts amongst

\author{
construction project managers
}

\begin{tabular}{|c|c|}
\hline HRM mechanism (Hiltrop, 1996) & $\begin{array}{l}\text { Implications for the successful } \\
\text { management of the psychological } \\
\text { contract in construction organizations }\end{array}$ \\
\hline $\begin{array}{l}\text { New methods for attracting and retaining people } \\
\text { (move away from career paths and security to } \\
\text { teamwork, challenge and skills enhancement). }\end{array}$ & $\begin{array}{l}\text { By marketing construction careers in terms of their team- } \\
\text { oriented, project-based nature this could reduce expectation } \\
\text { of promotion and reward amongst new entrants. }\end{array}$ \\
\hline $\begin{array}{l}\text { Align HR policies with social changes (encourage } \\
\text { employees to know more about management } \\
\text { decisions, contribute their own ideas, work } \\
\text { autonomously and be recognized for their } \\
\text { contribution). }\end{array}$ & $\begin{array}{l}\text { Construction organizations are well placed to use their short } \\
\text { reporting lines and high levels of empowerment to engender } \\
\text { involvement and commitment from their managers. } \\
\text { However, this is reliant upon effective communication, an } \\
\text { appropriate reward structure linked to individual } \\
\text { achievement and a genuine openness with employees. }\end{array}$ \\
\hline $\begin{array}{l}\text { Provide realistic job previews (illustrate both the } \\
\text { desirable and undesirable aspects of the job to avoid } \\
\text { unmet expectations in initial stages of employment). }\end{array}$ & $\begin{array}{l}\text { It is essential that those considering a construction career } \\
\text { are realistic about the nature of their future organizational } \\
\text { career and the opportunities available for vertical } \\
\text { advancement. }\end{array}$ \\
\hline $\begin{array}{l}\text { Offer challenging work experiences (by designing } \\
\text { jobs in a way which encourages self-development to } \\
\text { encourage commitment to the organization). }\end{array}$ & $\begin{array}{l}\text { De-layered structures offer an excellent opportunity for } \\
\text { project managers to take greater responsibility for their own } \\
\text { development and to derive benefit from their own } \\
\text { successes. }\end{array}$ \\
\hline $\begin{array}{l}\text { Balance professional and organizational } \\
\text { relationships (provide the opportunity for } \\
\text { employees to work towards their professional } \\
\text { aspirations outside of the organization). }\end{array}$ & $\begin{array}{l}\text { Most project managers have additional professional } \\
\text { interests outside of their organization through their } \\
\text { institutional affiliations. Promoting their opportunities to } \\
\text { develop these interests is mutually beneficial to both } \\
\text { organizations and individual employees. }\end{array}$ \\
\hline $\begin{array}{l}\text { Reward and recognize high achievement (by } \\
\text { rewarding contribution rather than status this should } \\
\text { encourage employees to serve beyond their job } \\
\text { description). }\end{array}$ & $\begin{array}{l}\text { Project teams are temporary and cross-functional, and so } \\
\text { reward structures should be designed to encourage all } \\
\text { employees to contribute beyond their job description, } \\
\text { particularly project managers who have to display a } \\
\text { multiplicity of different competencies to manage effectively. }\end{array}$ \\
\hline $\begin{array}{l}\text { Create or strengthen the firm's staffing systems } \\
\text { (any change in the psychological contract requires a } \\
\text { review and rethink of the entire employment } \\
\text { process. Exit survey data is invaluable for gaining } \\
\text { an understanding of the unfulfilled aspects of } \\
\text { outgoing employees needs). }\end{array}$ & $\begin{array}{l}\text { Every aspect affecting the employment relationship, from } \\
\text { induction programs to exit interviews, should be designed to } \\
\text { promote the same messages with regards to how } \\
\text { employees are valued by the organization and how they can } \\
\text { develop within it. }\end{array}$ \\
\hline
\end{tabular}

